\title{
Failure factors of Makkah's mega construction projects: qualitative study
}

\author{
Nashwan Al-Emad ${ }^{1, *}$, Ismail Abdul Rahman ${ }^{1}$, and Humair Khan ${ }^{2}$ \\ ${ }^{1}$ Department of Building and Construction Engineering, Faculty of Civil and Environmental \\ Engineering, Universiti Tun Hussein Onn Malaysia, 86400 Parit Raja, Batu Pahat, Johor, Malaysia. \\ ${ }^{3}$ Saudi Arabian Baytur Construction Co., P.O.Box.17606, JODP Phase II, MAKKAH K.S.A.
}

\begin{abstract}
Makkah city in Saudi Arabia is the holiest place for all Muslims across the world due to the presence of Masjid Al-Haram where the "KAABA" is located. In the holy city of Makkah, mega construction projects are currently under construction to accommodate the increased numbers of pilgrims. These mega projects faced many impediments and challenges to be completed successfully. Hence, this paper presents an investigative study on failure factors of mega Makkah construction projects, particularly from the site management viewpoint. The insight issues are based on interview with senior manager having 15 years of working experiences in handling mega construction projects. The interview was carried out on open-ended mode where ample time was given to the respondent to express his experienced in handling Saudi's construction projects. This study uncovered that $50 \%$ of project failure is due to contractor, $30 \%$ is due to client/PMC (Project Management Consultant), $15 \%$ is due to supervision consultant and 5\% is due external factors. It also identified 58 failure factors and clustered in 4 groups in which the group are Client Instigated Factors with 17 failure factors, Contractor Instigated Factors with 27 failure factors, Consultant Instigated Factors with 10 failure factors and External Instigated Factors with 4 failure factors. The findings are helpful for construction community as well as to researchers to understand the insightful issues engulfing construction projects in Makkah city.
\end{abstract}

\section{Introduction}

Makkah city is the most populous city in Saudi Arabia and it is located in western part of the country. It is considered as the holiest site for Muslims all across the world due to the presence of the Al-Haram Mosque which in its premises contains the "KAABA" where Muslims are required to perform Hajj at least once in their lives, where Umrah is optional in the city of Makkah. Due to the religious significance of the Al-Haram mosque, Muslims from across the globe travel to the city of Makkah for performing annual Hajj. Makkah city receives around 2 Million pilgrims during annual Hajj and for the rest of the year more than 20 million people visit the city for performing Umrah. The real estate, infrastructure,

\footnotetext{
*Corresponding author: df080116@gmail.com
} 
hospitality and retail sectors are the most attractive enterprise for this development. Demand for hotel rooms in the city of Makkah is very high, especially during Ramadan and Hajj season. The hotels are usually fully occupied during these seasons. However, with availability of numerous hotels, Makkah city still has lack of sufficient rooms to accommodate the visitors. Based on Mostafa \& Al-Buzz [1], more than USD100 billion has been allocated for the construction projects which are being constructed in Makkah city including Grand mosque (Al-Haram mosque) in order to improve services being rendered to Millions of pilgrims who come for Hajj and Umrah. According to Elawi [2] the expansion of the Holy Mosque has costed the government around USD10.6 billion in just a span of 6 years (2010 to 2015). A number of mega and popular projects are available and currently under construction in Makkah city that include the Abraj Kudai, Abraj Al-Bait (Makkah Royal Clock Tower Hotel), expansion of Grand Mosque, Jabal Omar development project, King Abdul Aziz Road (KAAR) etc. These construction projects faced failures in terms of completion timely, within budget, with high quality and according to safety requirement. Therefore, this paper tends to explore the failure factors of mega construction projects in Makkah city, Saudi Arabia.

\section{Construction projects failure}

In nature, construction industry is unique, complex, and diverse, thus this industry always encounters number of challenges and issues such as time overrun, cost overrun, poor quality, poor safety etc. which have negative impacts in achieving construction projects successfully. Based on Nasaruddin \& Rahman [3], construction projects are considered fail if it faces cost and time overruns, not meeting the required quality as stipulated in the contract document and faced with safety issue during the construction.

\subsection{Time overrun}

Time Overrun in construction projects is one of the major problems that encountered by construction industry globally. Based on Al-Emad \& Nagapan [4], time overrun is one of the substantial issues engulfing the construction industry in completing the project within the agreed duration. Time overrun can be defined as the extension of time either beyond completion date specified in a contract or beyond the date that the parties agreed upon for delivery of a project [5].This problem can lead to many negative effects such as lawsuits between owners and contractors, increased costs, loss of productivity and revenue, and contract termination [6]. In Saudi Arabia, time overrun is one of most crucial problem faced by Saudi Arabia construction industry. This reported by Assaf \& Al-Hejji [5] that 70\% of projects faced time overrun with average time overrun of $10 \%$ to $30 \%$ of the original duration of the project. Whereas, Elawi et al. [7] found out that the average delay in infrastructure projects is $39 \%$ and the 5 top factors contributing to construction delay in Makkah province are land acquisition, contractor' lack of expertise, re-designing, line services (Utilities and underground services), and clashes with other ministries. Rahman et al. [8] outlined that the factors related to client and consultant group is the most dominant group that influences the construction projects in Makkah city. Al-Emad [9] has identified the 10 most significant factor causing construction delay in Makkah's construction industry include difficulties in financing project by contractor, poor coordination between parties, shortage of manpower, delays in producing design documents, Improper planning and scheduling of the project, delay in progress payments, low productivity level of labour, poor communication between parties, unqualified workforce and poor contract management. 


\subsection{Cost overrun}

Cost overrun is a very frequent phenomenon and is almost associated with nearly all projects in the construction industry [10]. Cost is among the major considerations throughout the project management life cycle and can be regarded as one of the most important parameters of a project success [11]. Cost overrun is known as cost escalation, cost increase, or budget overruns [12]. Also, cost overruns is the difference between the original cost estimate of project and actual construction cost on completion of works of a commercial sector construction project[13]. Reina \& Angelo [14] highlighted that cost overruns are a major problem in both developing and developed countries. In developing countries the actual cost exceeded $100 \%$ of the anticipated cost of the projects [10]. Design changes, inadequate planning, unpredictable weather conditions; and fluctuations in the cost of building materials are common factors leading to cost overruns [11]. Similar situation exists in Saudi Arabia's construction industry which faces cost escalation problem. This issue is the most critical failure in infrastructure projects in Saudi Arabia [15]. Material cost, incorrect planning, previous experience of the contractor, contract management, and poor financial control on site are factors contributing to high construction cost are the main factors that affect construction costs in Saudi Arabia [16]. Besides that, the most factors affecting cost overrun in road construction projects in Saudi Arabia are internal administrative problems, payments delay, poor communication between construction parties, and delays in decision making [17].

\subsection{Poor quality}

Steering construction projects towards high quality performance with low cost and delay is a greater concern of project stakeholders. Quality of the works can be defined as meeting the customer's expectations, or compliance with customer's specification according to appearance, performances, and reliability of the project for a given price range [18]. Quality is crucial aspect because it is required to meet project requirements of the owners, constructors and other parties involved with a greater satisfaction [19]. However, Mallawaarachchi \& Senaratne [20] indicated that high quality is not always the primary objective for the client; but also it is extremely important to a successful project. According to Ali \& Wen [19], poor quality in construction projects is a common phenomenon in the world. Also, it is very common and serious problem as the expected quality is not complied in the construction projects [21]) cited by Memon [22]. Failure in achieving required quality has significant impact of project cost. Poor quality could lead to unnecessary cost to the organization where it could create extra costs due to failure, appraisal and prevention [19].

\subsection{Poor safety}

One of the most hazardous industries is the construction industry [23] and it is known a high risky industry because of its high risk of accident occurrence [24]. Poor safety can lead to accidents and fatalities which affect significantly on efficiency and cost of the project. Construction hazards lead to loss of life, injuries, disease and permanent disability. Health and safety issues have always been a major problem and concern in the construction industry [22]. According to Enshassi [25], accidents on construction sites not only have negative impacts to workers but also to the project performance such as productivity, quality, time, and affect the environment then consequently add to the cost of the project. Among the factors that lead to the construction accidents are workers' negligence, failure of workers to obey work procedures, work at high elevation, operating equipment without 
safety devices, poor site management, harsh work operation, low knowledge and skill level of workers, failure to use personal protective equipment and poor workers attitude about safety [24]. Besides that, poor management and control is the most important reasons leading to accidents at construction place [26]. In Saudi Arabia, poor safety in construction industry is one of substantial issues that influence project performance. Alshemimry [27] stated that in Saudi Arabia, the numbers of fatalities are increased due to improper health and safety measures at construction sites. More than 50 workers were trapped after the collapse of a building under construction [28]. Press Television also reported that another 4 workers were killed in another building site collapse [29]. Gul \& Ali [30] reported that 111 people were killed and 394 were injured due to a crane collapses in bad weather, crashing onto the Grand Masjid in Makkah city. These numbers of Health and Safety fatalities at constructions industry indicates that the industry has a poor record and serious issues which requires imperative attention by construction practitioners as well as authorities.

\subsection{Workers issues}

Construction workers are considered vital components to all industries including the construction industry where the construction tasks can not be executed without the involvement of skilled, semi-skilled or unskilled workers [31]. With the engagement of these workers many related problems are engulfing construction industry. Issues are not only related to the direct execution tasks which affect the project goal but also related to their social and cultural lifestyle. According to Yankov \& Kleiner [32], one of the challenges in construction projects is selection of quality workforce. This issue has become an important in the construction industry in recent years because there is a growing shortage of qualified workers in the field. Based on Pramanik \& Chackrabarti [33], most of construction workers are illiterate and ignorant about market conditions and labour market variations. Availability of skilled and unskilled construction workers, low productivity level, lack of experience, human injuries, long working hours, discrimination based on nationality are problems faced by construction workers [32,34]. Same situation in Saudi Arabia where many problems and challenges faced by construction workers such as low productivity level, shortage of skilled workforce, poor living condition, low wages, delay in salaries payment, non-provision of proper transportation, injuries, homesickness, fatalities etc. $[34,35]$. These problems have an adverse impact to construction project performance and require a serious attention by construction stakeholders.

\section{Methodology}

This study was carried out based on investigative and qualitative mode to uncover the factors that lead to projects failure in Makkah city, Saudi Arabia. It was conducted through open-ended interview with a senior manager who has more than 15 years of working experiences in handling mega construction projects internationally \& around 5 years in Saudi Arabia's construction industry. The expert has master degree qualification and involved in many mega construction projects worldwide. Prior to the interview session, the objectives and questions to be asked were designed to ensure that the expert shared all his experiences regarding failures of construction projects. Interview session was conducted in face to face mode where all the given information was captured manually and also electronically. Expert was given ample time to voice his opinions on the given topic and gently guided to avoid deviation from the interview's objectives. At the beginning of the interview, the expert was requested to describe his educational background and involvement in construction industry. Subsequently, requested to share opinion regarding 
the causes contributing to projects failure. The information gathered from the interview was converted into transcription for analysis part.

\section{Projects' failure factors}

This study uncovered that $50 \%$ of project failure is due to contractor, $30 \%$ due to client/PMC, $15 \%$ due to supervision consultant and 5\% external factors. This study also identified 58 failure factors and then classified into 4 main clusters which are Client Instigated Factors, Contractor Instigated Factors and Consultant Instigated Factor and External Instigated Factors.

Table 1 shows the clusters of identified failure factors of Makkah's construction industry. Each cluster consists of several inter-related factors which are being highlighted by the expert during the interview session.

Table 1. Failure factors clusters.

\begin{tabular}{|c|l|c|}
\hline Nos. & Cluster & Numbers of related Factors \\
\hline 1 & Client Instigated Factors & 17 \\
\hline 2 & Contractor Instigated Factors & 27 \\
\hline 3 & Consultant Instigated Factors & 10 \\
\hline 4 & External Instigated Factors & 4 \\
\hline \multicolumn{2}{|c|}{ Total } & 58 \\
\hline
\end{tabular}

Elaborations of these 4 clusters of failure factors are discussed as in the following subsections.

\subsection{Client instigated factors}

According to the interview session, Client Instigated Factors group is defined as the factors that are initiated by client or his agents and it contributes negatively to project failure. It consisted of 17 failure factors; the first failure factor mentioned by the expert is that interference of client in contractor's responsibilities by influencing the appointments of individuals and subcontractors of their choice or acquaintance. Second factor is unconventional project specifications where Middle East in general and Saudi Arabia specially is not aligned with American standards, British standards are more popular therefore projects with American specification faces the burnt, procurement delays, cost overruns are very visible impact where the client's requirements are not flexible. According to the expert the third factor is that clients in private sector don't have much experience in mega construction projects in Saudi Arabia where most of the development is government led, especially the western province hasn't seen many mega projects, therefore to mobilize an expert team is a challenge that can share their experience and proactively highlight all the associated risks. Additional, the client faces restriction if the construction projects are located in the holy land where Non-Muslims are restricted to come in; in these cases they have offsite offices outside the holy cities and thus end up with miscommunication from the client's site management. Moreover, strategic level failure when the goals are not clear since the beginning of the project, lack of coordination between sales, commercial, technical \& project management team exaggerate the failure of the projects. The expert added that, lack of management system framework. According to him, frequent changes in client's management board which affects completion of project 
timely where every manager come with his vision and objectives which contradict with overall project's goals. To a certain extent, mega projects generally have international consultants thus managing the consultants from abroad is always a challenge, these consultants local teams are mostly dummy and act as a postman, thereby results in delays in getting design information. Also coordination of these consultants' trips and getting the best outcome of their trips is also not achieved due to non-clarity \& poor management from the client's side.

Another factor that contributes to project's failure which highlighted by the expert is the lack of experience and knowledge with client to identify the key consultants and writing their contracts accordingly, in case of project overruns, the specialist consultants' charges extra for any input they provide thereby affecting the client's budget. Besides, change management: lack of understanding of clients' agents that any instruction is a change and any change has time \& cost impact also adds to the situation. Furthermore, ethical: Financial malpractices are not uncommon as compared to other parts of the world; conflict of interests among senior management also contributes to derailment of the projects. Also, lack of will within senior management to complete project due to longer project duration benefits the employer agents if there are limited checks \& balances as it ensure employment for longer duration, legal disputes are very lengthy process in general; therefore majority of the disputes ends up in compromise which unfortunately works in favour of client agents to have disputes to elongate the process and collusion of the client agents with contractor and other parties with common interest elongate the project duration to benefit each other. In the interview session, the expert has pointed out that poor administration and management of the contracts from client side, due to limited availability of qualified professionals; traditional practices of management are prevalent which may work in small projects but definitely fails in mega projects. And also because of limited professional understand the administration of a contract; people don't pay attention to what one is obliged to perform under a contract, what are their roles \& responsibilities \& how to protect their interest. Interference by client in consultant's tasks and not providing them enough support and authority to perform is another factor identified by the expert. Likewise, interference of the client in contractors and subcontractors scope also contributes to the derailment of project. Additionally, involvement of client in the approval process of subcontractors \& suppliers is unfortunately misused by the client agents as an opportunity to bring the firms related to them which encourages corruption at every level. Also, the expert stated that No check \& balances or guidelines availability with the client agents as to what can be considered as a gift, favor \& a bribe. Contractor/Subcontractors take the advantage and in the excuse of hospitality influence the client's decision making. Finally, responsibility with authority is mostly missing, site agents of clients have responsibilities but are not authorized to take any decision which delay in decision making and ends up getting into the loop of coordination.

\subsection{Contractor instigated factors}

The expert has defined Contractor Instigated Factors group as the factors or causes which are initiated by contractor that can contribute adversely to project failure and it consisted of 27 failure factors. The expert has highlighted several factors related to this group including complex construction contract where the responsibilities are not well defined. This involves the contractor signs the contract to secure a job without comprehensive/detailed study, lack of transition between pre-contracts $\&$ the site team, lack of formal handover and assistance by the pre-contracts team to the site management. Besides that, lack of competent staff in the contractor's organization to understand the finite details of complex construction contracts. Moreover, inability to mobilize the qualified staff from the beginning and keep them motivated for the delivery of the project. Likewise, frequent changes in the functional 
and strategic management where new management comes with new vision and strategies. In addition to that, lack of team building leading to non-cohesion among different nationalities which impacts the project objectives. And also, non-clarity of objectives and goals, also roles and responsibilities are not identified for the staff \& site team and also absence of project integration plan \& vision document. Most important factor causing project failure is that inefficient procurement system in the contractor's organization which leads to late appointment of subcontractors and suppliers. Furthermore, poor decision making of financial management departments, where subcontracts are unfairly awarded without following the proper vetting procedures. To a certain extent, improper risk management at various levels including logistic risks, health \& safety risks, operational/construction risks, commercial risks and engineering risks. These risks never get reviewed periodically and no risk mitigation plan is either prepared or put in effect by the site management. Sticking with the traditional practices of construction is a very relevant factor that resulted in delays where mega projects need a fresh approach and a close coordination between different departments which is generally missing. Under Utilization of technology in the construction projects is one of the key contributing factor, very few projects may have the EDMS (Electronic data management system), BIM (Building information modelling). Project integration tools, reporting \& presentation software. Contracting organization don't encourage investment in the technology as they see it as a one off project and don't share the expenses with the other projects thereby any investment becomes unfavorable.

The expert has stated that financial malpractices are the most sever factor affecting projects success. These include firstly unfair recruitment of staff where the recruitment is conducted based on relationship, favoritism and nationality not based on merit, secondly, unfair distribution of wages, where the salaries are distributed based on favoritism nationality or relationship and finally conducting unfair commercial quality audit by giving wrong data or manipulating the data. Similarly, corruption and conflict of interests while procuring suppliers and subcontractors, contractor is not following the procedures effectively. For instance, senior management owned private companies and dummy businesses being appointed to run certain portions of jobs in the project. It also noted that sometime the actual work being done by main contractor resources (material and manpower) but its reflected as a subcontractor performed works where the subcontractor is paid for the works which they have not performed thus damaging the cash flows. In addition to that, stealing sub-contractor materials by main contractors and threatening them for not reporting and harassing them by not releasing their payments. Another important factor brought up by the expert is that, contractor's delaying payments of suppliers and subcontractor, thereby damaging their cash flow which in turn affects the projects. Besides, non-payment of staff \& workers' salaries on time as well as threating them against taking any legal recourse is one of the crucial factors which affect completion of project's milestones timely. Another form of project failure is due to using unapproved materials and dubious products at site and working in non-office hours and putting unapproved substandard products while consultants are away. Several failure factors can be categorized under construction stage such as compromising the quality standards due to hiring unskilled workers and using unapproved substandard materials; improper safety compliance: saving the money allocated to safety at site while carrying out the construction tasks which lead the safety budget to compromise and thus substandard safety products \& practices are used which ultimately lead to injuries and fatalities; poor planning: not investing enough time to plan activities but to invest in earning from delay claims; improper execution: trying to trap client with high volumes of improper execution so that client is pressurized to accept the poor quality of works in order to avoid delay; inaccurate reporting: keeping the client uninformed about the actual works and not showing the real 
picture to the client \& consultant; sticking to traditional practices of construction; lack of utilization of available modern methods of construction e.g. offsite construction technology, prefabrication, assembling items etc.; using untrained workforces compromising the quality in the construction \& lack of emphasizing developing the staff \& workers by training \& upskilling workshops. Furthermore, poor coordination between main contractor and other stakeholders including client, consultant, subcontractors and suppliers led to project delays. Moreover, lack of capabilities of senior management such as poor leadership, lack of vision, lack of decision taking capacities,; poor resource planning; poor time management; insufficient experience in mega construction projects; not creating a culture of teamwork and not being able to motivate employees with either monetary or non-monetary benefits.

Within contractor organization the role of Human resource department is often subdued however as per the experts opinion HR department is a key contributing factor in delaying the projects, delaying renewal residency permit (IQAMA) and health insurance, absenteeism of grievance reporting system in the company, complete absenteeism of training and skill development culture from Absence of progression plan \& knowledge management system are the key contributing factors in project delays. Another factors leading to project failure is non availability of lessons sharing platform, people are expected to be focused on their tasks rather than finding the out of box solution, i.e. critical thinking is not encouraged. Also, instilling fear among the staff by sudden unfair termination of employment contracts which not only denigrate the individuals moral but also affect the decision making ability of the employees leading to unreported mental health issues. In addition to that, ineffective organization charts where people are there just to fill certain positions but are not authorized to take any relevant decisions. Finally, exploiting the traditional culture of respect where questions are not being asked by the employees lower in the hierarchy, also contribute to go certain decisions go unchecked thereby reducing the collaborative decision making and ends up in autocratic management of projects and compromises the teamwork spirit.

\subsection{Consultant instigated factors}

Several failures factors were highlighted by the expert during interview session which originally initiated by supervision consultant and it comprises of 10 failure factors. The expert highlighted the first failure factor which is incompetent staff in the consultant's organization with limited or no experience of inspection thereby affecting the final product quality. Besides, corruption among staff \& financial malpractices, accepting the gifts from contractors thereby returning favors is one of the crucial factors which affect project's progress adversely. Furthermore, lack of quality objectives set up from the beginning of the project also impacts the project progress and quality.

In addition to that, disproportionate focus on minor details and missing the bigger picture which is timely hand over the project. Also, wasteful bureaucracy, unnecessary documentation is another cause can lead to a project failure. Besides that, reluctance to adapt new technology such as Electronic Documents Management System (EDMS) and continuing using traditional documentation which can contribute to slow productivity of project. Likewise, poor resource planning and poor time management are vital causes affect project completion. To a certain extent, behaviors and cultural issues are important factors identified by the expert. Consultant in the Middle East countries enjoys the luxury of excessive respect from the contractor which encourages a fake sense of pride among the consultant which ultimately led them to delay the approvals not acting in timely manner and enjoys the backing of client in their position. However, in other part of the world consultant collaborate as team member to accomplish the job. Finally, the expert stated that 
financial malpractices in approving sub-contractors and suppliers are normal practices among consultants in Saudi's construction industry.

\subsection{External instigated factors}

The expert has defined this cluster as factors that occurred due to restricted rules and laws from government bodies or unexpected incidents beyond human control. This involves abrupt change in the legislation of the country without prior notification, inappropriate demands including unchecked interventional by municipal authorities. Besides, unknown safety requirement which could potentially be restricting the usage of tower cranes crane \& certain noisy operations, requirement of kitchen hygiene etc. And also, delay in approving drawings by regulatory authorities such as fire department \& building control department are the main factors affecting the progress.

\section{Conclusion}

Construction industry of Makkah city encounters numerous of challenges and problems which affect to complete project successfully. This requires more attention from the construction stakeholders to improve its performance and ensuring a successful construction projects. This paper has uncovered the failure factors which engulfed mega construction projects in Makkah city from the perspective of site management. This study has found that $30 \%$ of project failure due to Client/PMC, $50 \%$ due to contractor, $15 \%$ caused by supervision consultant team and finally external factors contribute approximately $5 \%$ to project failures. It also identified 58 factors causing project failures, these factors were then classified into 4 main clusters namely Client Instigated Factors with 17 failure factors, Contractor Instigated Factors with 27 failure factors, Consultant Instigated Factors with 10 failure factors and External Instigated Factors with 4 failure factors. The findings of this study are helpful for construction community in Makkah and whole Saudi Arabia as well as to researchers to understand the insightful issues engulfing construction projects in Makkah city.

\section{Recommendations}

Based on the interview session, several recommendations have been highlighted to construction stakeholders in Makkah city to ensure successful construction projects as summarized as following:

1. Project collaboration should be given utmost priority, stakeholders to work together for a coordinated project delivery in a more friendly and trustful environment.

2. Partnering should be encouraged, collaborative contracts should be encouraged where the responsibilities of any delay is shared. Teamwork is entirely missing where the bigger picture of timely project delivery appears lackluster.

3. Nature of the industry needs a revamping; currently the construction industry which is relying on expat construction workers makes it more complex, therefore automation \& mechanization of construction elements is quite important.

4. Stakeholders are advised to have offsite offices outside the holy cities to overcome the restrictions to Non-Muslim personals/experts.

5. Stakeholders should have consistent management system framework, thus to avoid frequent changes made by new appointed management. 
6. Construction players are strongly recommended in maintaining functional management from beginning till the completion date of a project, thereby avoiding project delay and cost overrun.

7. Use of Information Technology in coordinating and managing the construction activities must be strongly encouraged \& implemented.

8. In case of mega projects with mixed use, the project stakeholders priorities should be aligned, work breakdown structure to be prepared, planning, review \& continuous monitoring should be implemented during the course of the project.

9. Stakeholders should establish effective formal communication channels among all project parties throughout project lifecycle. Any decision affecting the project progress should be formal. Traditional practice of verbal commitments should be avoided.

10. Effective change management process should be implemented where clients is advised in a timely manner the consequences of any late decision.

11. Contractor should hire sufficient skilled workforces and motivate them to improve productivity.

12. Contractor should ensure the importance of safety rules and requirements to be followed strictly at site.

13. Contractor should manage their financial resources and plan cash flow by utilizing progress payment effectively and efficiently to avoid any disruption of the project's progress financially.

14. Contractor should distribute wages fairly based on skills and experience of the workers not based on nationality and favoritism.

15. To maintain high quality of work, construction companies should conduct regular audit on supervision team including Foreman and site engineers as well as construction managers.

16. Construction companies should improve its logistical requirements and arrangements.

The authors would like to thank and acknowledge Universiti Tun Hussein Onn Malaysia (UTHM) for the financial support using the grant name "Contract Grant A074 Renalcare Research Fund". Also, the authors would like to thank and appreciate the construction experts for their significant contributions to this research.

\section{References}

1. M. M. Mostafa, \& W. W. Al-Buzz. Calculation of the Construction Time- Systematic Management of Project Uncertainties in Rush Projects in Makkah. International Journal of Research In Engineering And Technology, Vo. 04, Issue: 05, (2015)

2. G. S. A. Elawi. Owners' Perspective of Factors Contributing to Project Delay: Case Studies of Road and Bridge Projects in Saudi Arabia. Arizona State University: Master Thesis, (2015)

3. N. A. N. Nasaruddin, I. A. Rahman. Leadership Quality for Malaysia Construction Leader to Steer a Success Construction Project. In MATEC Web of Conferences (Vol. 47). EDP Sciences, (2016)

4. N. H. Al-Emad, S. Nagapan. Identification of delay factors from Mecca's construction experts perspective. International Journal of Sustainable Construction Engineering and Technology, 6 (2), 16-25, (2015)

5. S.A. Assaf and S. Al-Hejji, Causes of delay in large construction projects, Int. J. of

6. Project Management, 24(4), 349-357, (2006)

7. W. Menesi. Construction Delay Analysis under Multiple Baseline Updates. University of Waterloo: Master Thesis, (2007) 
8. G. S. A Elawi, M. Algahtany\& D. Kashiwagi. Owners' Perspective of Factors Contributing to Project Delay: Case Studies of Road and Bridge Projects in Saudi Arabia. Procedia Engineering, 145, 1402-1409, (2016)

9. I. A. Rahman, N. Al-Emad, \& S. Nagapan. Projects delay factors of Saudi Arabia construction industry using PLS-SEM path modelling approach. In MATEC Web of Conferences (Vol. 81, p. 07001). EDP Sciences, (2016)

10. N. Al-Emad. Structural relationships model of delay factors in Makkah construction industry (Master dissertation, Universiti Tun Hussein Onn Malaysia, (2016)

11. N. Azhar, R. U. Farooqui \& S. M. Ahmed. Cost overrun factors in construction industry of Pakistan. In First International Conference on Construction In Developing Countries (ICCIDC-I), Advancing and Integrating Construction Education, Research \& Practice (pp. 499-508), (2008)

12. A. H. Memon, I. A. Rahman, M. R. Abdullah \& A. A. A. Azis. Factors affecting construction cost in Mara large construction project: perspective of project management consultant. International Journal of Sustainable Construction Engineering and Technology, 1(2), 41-54, (2011)

13. L. Liu \& K. Zhu. A stage-by-stage factor control framework for cost estimation of construction projects. J. Constr. Eng. Manage, 133(1), 91-95, (2007)

14. A. P. Chan. Time-cost relationship of public sector projects in Malaysia. International journal of project management, 19(4), 223-229, (2001)

15. P. Reina \& W. J. Angelo. Megaprojects need more study up front to avoid cost overruns. ENR, 249 (3), (2002)

16. D. I. Ikediashi, S. O. Ogunlana \& A. Alotaibi. Analysis of project failure factors for infrastructure projects in Saudi Arabia: A multivariate approach. Journal of Construction in Developing Countries, 19(1), 35, (2014)

17. A. A. Bubshait \& Y. A. Al-Juwairah. Factors contributing to construction costs in Saudi Arabia. Cost engineering, 44(5), 30-34, (2002)

18. A. Alhomidan. Factors affecting cost overrun in road construction projects in Saudi Arabia. International Journal of Civil \& Environmental Engineering, IJEEIJENS, 13(3), (2010)

19. K. N. Jha \& K. C. Iyer. Critical factors affecting quality performance in construction projects. Total Quality Management and Business Excellence, 17(9), 1155-1170. (2006)

20. A. S. Ali \& K. H. Wen. Building defects: Possible solution for poor construction workmanship. Journal of Building Performance, 2(1), (2011)

21. H. Mallawaarachchi \& S. Senaratne. Importance of Quality for Construction Project Success, In international conference on structural Engineering and construction management, Kandy, Srilanka, (2015)

22. T. S. Kometa \& P. O. Olomolaiye. Factors influencing construction client's decisions to build. Journal of Management in Engineering, 13(2), 77-86, (1997)

23. A. H. Memon. Structural Modelling of Factors Causing Cost Overrun in Construction Industry. Universiti Tun Hussein Onn Malaysia: Ph.D Thesis, (2013)

24. A. Enshassi, J. Al-Najjar \& M. Kumaraswamy. Delays and cost overruns in the construction projects in the Gaza Strip. Journal of Financial Management of Property and Construction, 14(2), 126-151, (2009)

25. A. R. A. Hamid, M. Z. A. Majid \& B. Singh. Causes of accidents at construction sites. Malaysian journal of civil engineering, 20(2), 242-259, (2008) 
26. A. Enshassi. Factors Affecting Safety on Construction Projects. Islamic University of Gaza, Gaza Strip, Palestine, (2003)

27. T. Baxendale \& O. Jones. Construction design and construction management safety regulations in practice - Progress and implementation. International Journal of Project Management, 18(1), 33-40, (2000)

28. A. Alshemimry. An investigation of health and safety issues in Saudi Arabia's construction projects: challenges and solutions. University of Central Lancashire: PhD Thesis, (2016)

29. Workers killed in Saudi construction collapse: Retrieved on December 2017 from http://www.aljazeera.com/news/2015/04/workers-killed-saudiconstruction- collapse150427172925152.

30. PressTV-4 killed in Saudi building collapse: Retrieved on November 2017 from http://www.presstv.com/Detail/2015/04/27/408395/Saudi-Arabia-buildingcollapseQassim-university-Buraydah

31. F. A. Gul, \& A. M. Ali. Saudi Crane Collapse Masjid al-Haram (Lack of Safety). IJRDO-Journal of Social Science and Humanities Research, 1 (8), (2016)

32. M. Loosemore, A. Dainty \& H. Lingard. Human resource management in construction projects: strategic and operational approaches. Taylor \& Francis, (2003)

33. L. Yankov \& B. H. Kleiner. Human resources issues in the construction industry. Management Research News, 24(3/4), 101-105, (2001)

34. S. Pramanik \& S. N. Chackrabarti. A study on problems of construction workers in West Bengal based on neutrosophic cognitive maps. International Journal of Innovative Research in Science, Engineering and Technology, 2(11), 6387-6394, (2013)

35. R. Almannaee. Migrant workers in the construction industry in United Arab Emirates (UAE): The role of the Ministries of Labour and Foreign Affairs in enforcing fair payments and minimum wages M.Sc. Thesis (The Hague: Int. Institute of Social Studies) pp 11-64, (2014)

36. J. B. Andrieu, A. Ucla, M. Lee. Addressing workers' rights in the engineering and construction sector - Opportunities for collaboration BSR Working Paper (San Francisco: Humanity United) pp 12-38, (2016) 